\title{
TELEOLOGIA E METODOLOGIA HISTÓRICAS EM TÁCITO*
}

\author{
Fábio Duarte Joly**
}

\section{Resumo}

Este artigo analisa o modo como Tácito, em seus Annales, concebe o princípio de verdade de sua narrativa histórica e as relações que este guarda com a poesia, sobretudo a tragédia discutida por ele no Dialogus de oratoribus.

Palavras-chaves: Historiografia, verdade, poética, Tácito.

Ao finalizar o breve proêmio de seus Anais, Tácito expõe como teleologia de sua narrativa histórica a asserção da verdade:

De Tibério, Caio, Cláudio e Nero, enquanto vivos o medo não deixou falar com verdade; depois de mortos, o ódio recente falseou as narrativas. Eis porque empreendi narrar, de Augusto pouco e seu fim, e depois o principado de Tibério e os seguintes, sem ira nem afeição, pois destas causas mantenho distância. (Ann., I, 1)

* Este artigo deriva de um trabalho de conclusão do curso "Memória Histórica e Narrativa Historiográfica", ministrado pelo Prof. Dr. Francisco Murari Pires (FFLCH/USP) no primeiro semestre de 1999. Resulta também de pesquisa de mestrado sobre Tácito, realizada sob orientação do professor Dr. Norberto Luiz Guarinello, com financiamento da FAPESP.

** Mestre em História Econômica pela USP. 
Estas considerações "metodológicas" tendem a ser, em maior ou menor grau, entendidas pela crítica moderna como uma proposição de que a narrativa taciteana pretende ser uma reconstituição verdadeira do passado, nos moldes da fórmula rankeana de relatar "o que realmente aconteceu" (wie es eigentlich gewesen) (BACHA, 1906; GOODYEAR, 1983; LASTNER, 1977; BAyET, 1996). ${ }^{1}$ Constatando que, ao longo da obra, tal concepção de verdade não se realiza, os estudiosos, sejam historiadores sejam críticos literários, atribuem a impossibilidade de sua realização, por um lado, a um viés parcial de Tácito sobre o passado, como se negasse a proclamação de imparcialidade do proêmio, e, por outro, ao papel da retórica em sua narrativa. Enquanto os historiadores alegam que, para fazer a verdade dos fatos emergir, é necessário desconsiderar os julgamentos dos fatos por Tácito e a apresentação retórica dos mesmos (MARsh, 1931, p. 6), os críticos literários, devido a esta retórica do discurso histórico, descartam mesmo qualquer possibilidade de se depreender algo de verdadeiro nos escritos de Tácito. Em ambas as abordagens, é, portanto, nítida a oposição entre retórica e verdade, conseqüência da herança epistemológica positivista do século XIX, acompanhada de uma descaracterização da retórica antiga que eclipsa sua função de pesquisa da verdade ao associá-la exclusivamente à composição estilística (WOODMAN, 1998a, p. 6-18; 1998d, p. 236).

Neste sentido, a questão que se formula é a da delimitação do conceito de verdade esboçado por Tácito, no contexto da estruturação retórica de sua narrativa, que não o (pré)definido pela convenção positivista. Com o intuito de apresentar uma reflexão sobre esta problemática, delineamos um percurso que inclui alguns passos de uma análise do proêmio dos Anais, procurar-se-á comentar o princípio teleológico nele exposto, no caso, a projeção da verdade como meta da narrativa histórica. Esta questão desdobra-se em outra, a da metodologia da narrativa taciteana, ou seja, os preceitos pelos quais fundamenta a veracidade de sua composição. Esta discussão será conduzida com outras passagens relevantes dos Anais, relativas a sua crítica das tradições, orais e escritas, sobre o passado (principalmente Ann., IV, 10-11) e à retórica de seu método aí operante (Ann., XIV, 43-44). A questão da verdade tratada nestes pontos conduz, por sua vez, estando ela inclusa, à utilidade da história como crítica da sociedade presente por sua comparação ao passado (Ann., IV, 32-33). Ao final, uma análise da 
teleologia poética, como apresentada no Diálogo dos oradores, obra anterior aos Anais, tem por objetivo demonstrar como a teleologia histórica de crítica social representa, de certa forma, um desdobramento dela.

Uma arqueologia do principado

A princípio foram reis os que governaram a cidade de Roma. L. Bruto instituiu o consulado e a liberdade. As ditaduras eram temporárias; e o poder dos decênviros não durou mais de dois anos, nem por muito tempo o dos tribunos militares. Foi curta a dominação de Cina, como também a de Sila; e o poder pessoal de Pompeu e Crasso passou logo para César, como também as armas de Lépido e Antonio foram suplantadas pelas de Augusto, quem aceitou o governo, sob o nome de príncipe, cansados que estavam todos das discórdias civis. (Ann., I, 1)

Na primeira parte do proêmio dos Anais, Tácito, com singular concisão, oferece ao leitor uma seqüência progressiva de acontecimentos que antecedem o fato a ser narrado, o estabelecimento do principado, indicando, ao final, sua causa. Ao declarar o princípio arqueológico, simultaneamente, o encadeia com um princípio etiológico.

Inicialmente, enumera eventos políticos da história de Roma em ordem cronológica, tripartindo-a segundo as três formas de governo que definem sua evolução política, a saber, monarquia, república e principado. O eixo a partir do qual apresenta esta sequência é o tema do poder (reges, consulatum, dictaturae, potestas, dominatio, potentia, arma, imperium), o qual, por sua vez, é subdividido em duas categorias, legalidade (consulatum, dictaturae, potestas, consulare ius, imperium $)^{2}$ e ilegalidade (dominatio, potentia, arma). Funcionários do Estado (decemviralis, tribuni militum, dictator) exercem os poderes legais, enquanto os ilegais são detidos por particulares (Cinna, Sulla, Pompei Crassique, Lepidi atque Antoni).

As frases em que estes termos aparecem não estão subordinadas entre si por relações de causalidade. Tácito apenas registra cada evento político não indicando ao leitor as razões da extensão temporal ( $a d$ tempus, neque ultra biennium, neque diu, non longa, cito) dos poderes 
que se sucederam. Seu objetivo é o de tão somente mostrar que a história de Roma, até a ascensão de Augusto, que então estabeleceu um regime permanente (JENS, 1956, p. 346), caracterizou-se por uma alternância entre legalidade e ilegalidade.

Nesta "arqueologia do principado", portanto, está subjacente o tema do poder. As disputas pelo poder político em Roma culminaram nas guerras civis do final da República, conflito que é a causa factual do principado: qui cuncta discordiis ciuilibus fessa nomine principis sub imperium accepit. Se, contudo, é clara nesta frase a definição da causa do principado, não o é o julgamento que Tácito tece sobre este regime, pois uma apresentação dual do principado está implícita nela. A frase acima pode ser lida de duas maneiras (ButTi DE LiMA, 1996, p. 5). Por um lado, significa que Augusto aceitou, dos que estavam fatigados pelas guerras civis, todos os poderes (cuncta accepit) sob um imperium (Murari Pires, 1999, p. 147-276; Neschke, 1978, p. 49). Porém, cuncta não é apenas complemento do objeto direto de accepit mas também sujeito lógico de fessa. Ou seja, também pode ser entendido que Augusto aceitou, sob um imperium, ${ }^{2}$ todas as pessoas fatigadas pelas guerras civis (WoOdMAN, 1998c, p. 66; Béranger, 1977, p. 332; MARINCOLA, 1997, p. 143).

Esta dupla apresentação do Principado deve ser compreendida tendo em vista a economia do proêmio, ou seja, relacionada com sua segunda parte, que aborda a questão da verdade na narrativa histórica. Ao justapor duas visões, uma positiva e outra negativa, sobre este imperador, Tácito introduz a questão das interpretações usualmente polarizadas acerca do regime imperial, fator, segundo ele, que dificulta a apreensão da verdade sobre o passado júlio-cláudio.

As temporalidades da verdade

Mas os antigos feitos do povo romano foram já narrados por ilustres escritores, assim como para o governo de Augusto não faltaram, até que a adulação crescente fosse corrompendo os mais formosos talentos. De Tibério, Caio, Cláudio e Nero, enquanto vivos o medo não deixou falar com verdade; depois de mortos, o ódio recente falseou as narrativas. Eis porque empreendi narrar, de Augusto pouco e seu fim, e depois o principado de 
Tibério e os seguintes, sem ira nem afeição, pois destas causas mantenho distância. (Ann., I, 1).

Neste trecho Tácito distingue três temporalidades do passado. Uma primeira, anterior ao principado de Augusto, circunscrita pelo que denomina de "antigos feitos do povo romano". Uma segunda é delineada pelo período de Augusto, enquanto uma terceira abarca os seus sucessores, de Tibério a Nero. Segundo Tácito, cada uma delas foi objeto de narrativas históricas, as quais, contudo, comparativamente diferenciamse quanto ao grau de veracidade. As narrativas referentes aos principados de Tibério, Caio, Cláudio e Nero, são classificadas em sua totalidade como falsas por Tácito. Logo, em contraponto a estas, sugere que as narrativas dos tempos antigos primavam pela veracidade e daí a qualificação positiva dos que as conceberam. Uma posição intermediária é ocupada pelas narrativas relativas ao principado de Augusto. Sobre estas diz que, por um momento, representaram uma continuidade com suas predecessoras, decaindo a seguir, fato que persistiu doravante. Mas com qual argumento endossa este comentário acerca da impossibilidade de se constituir um saber sobre o principado?

No tocante à historiografia imperial Tácito aventa o fato de o historiador ser um personagem do período histórico que narra como um elemento que oblitera a verdade de seu discurso. Enquanto os que escreveram sob Augusto, falsearam suas narrativas para elogiá-lo, aqueles que compuseram suas obras sob os imperadores júlio-cláudios tenderam a falsificá-las devido ao medo de serem punidos e, mesmo findos tais imperadores, tal falsificação persistiu, resultado de ódios pessoais, por injúrias sofridas. Tácito também aponta a adulação como um elemento que produz uma narrativa parcial. Com a finalidade de agradar o imperador, o historiador elabora um relato de cunho positivo, ausente de críticas. $^{3}$

Para Tácito, então, a verdade configura-se como uma categoria dependente da historicidade do historiador, reflexão fundada em uma relação entre historiografia e sistema político. As narrativas dos historiadores que escreviam sob a República, e que tinham por objeto os feitos do povo romano, podiam almejar a verdade já que não havia o monopólio do poder por um indivíduo. Deste modo, ao fixar uma ruptura com seus predecessores no campo da historiografia imperial Tácito sugere 
uma continuidade com estes representantes da historiografia republicana, os quais qualifica de magna ingenia e clari scriptores. Coloca-se como herdeiro do princípio teleológico destes, deslocando-o para a temática do principado, para os feitos dos imperadores.

No entanto, com esta problemática das temporalidades da verdade, Tácito também está a sugerir uma aporia informativa que lhe é conseqüente. Como oferecer uma narrativa que tenha a verdade como meta se ele, Tácito, depende da consulta às narrativas falsas, pois distorcidas pela parcialidade dos que escreveram durante e logo após os imperadores júlio-cláudios? Uma solução para esta aporia é apenas delineada no proêmio. Diz Tácito que irá narrar os principados de Tibério a Nero "sem ira nem afeição" (sine ira et studio), "mantendo distância destas causas" (quorum causas procul habeo) (Ann., I, 1). Como notou A. J. Woodman, causas procul habeo não é equivalente a nullas causas habeo, como tendem a compreender a primeira expressão aqueles estudiosos que projetam uma postura "positivista" a Tácito. Segundo esta correção, a idéia presente ao final do proêmio não é a de que a narrativa taciteana está completamente ausente de visões parciais sobre os imperadores, mas que estas não tem como fonte Tácito, pertencendo àquelas narrativas que o historiador consultou sobre o período júlio-cláudio. O que Tácito, ao final do proêmio, afirma ao leitor, é que está ciente da parcialidade das versões sobre o passado, por vê-las com um olhar distanciado (MARINCOLA, 1997, p. 252.). O historiador sugere que não irá aceitá-las acriticamente, mas que sua narrativa pautar-se-á por um juízo crítico, que possibilite uma apreensão do passado.

\section{O método da narrativa: a crítica das tradições}

Um dos procedimentos taciteanos de afirmação da veracidade de sua narrativa consiste no recurso à contraposição entre o julgamento do historiador sobre um acontecimento e as tradições concernentes ao mesmo, sejam escritas sejam orais. Não que Tácito descarte todas as tradições por ele recolhidas, mas seleciona-as de modo que determina quais são dignas de credibilidade e que, portanto, podem ser transmitidas, e quais devem ser abandonadas, visto que revelam um conhecimento insuficiente dos fatos (WoOdMAN, 1998b, p. 22). 
Quanto às tradições de cunho oral, um dos motivos pelos quais Tácito as vê com reticência é o fato de, segundo ele, originarem-se, sobretudo, nas camadas subalternas da sociedade romana. Populus, plebs e uulgus são termos que freqüentemente acompanham a apresentação de rumores por Tácito. Tais grupos são caracterizados como carentes de sabedoria e avessos à elaboração de um juízo crítico que almeje a verdade. ${ }^{4} \mathrm{O}$ apego ao fabuloso e a tendência ao engrandecimento dos fatos também são marcas negativas das tradições orais apontadas por Tácito (MARINCOLA, 1997, p. 93).

Por este motivo, advoga a necessidade de avaliá-las criticamente antes de aceitá-las e continuar sua transmissão. Tal exemplo deste seu método encontramos na análise que faz de uma determinada tradição oral, a concernente à morte de Druso, filho do imperador Tibério (Ann., IV, 10-11). A relevância deste episódio reside no fato de apresentar ao leitor a metodologia taciteana de averiguação das versões sobre o passado.

Narrando a morte de Druso, segui a maior parte dos autores e os mais fidedignos, mas não devo omitir um rumor muito propalado então e que até hoje não perdeu de todo o crédito. Constou que estando já Lívia seduzida para o crime, Sejano ligara a si por impudico comércio o eunuco Ligdo por sua idade e beleza muito caro ao senhor e predileto entre seus escravos: depois, quando ficou entre os cúmplices combinado tempo e lugar do crime, chegou-se à audácia de inverter as coisas, avisando ocultamente Sejano a Tibério que no jantar em casa do filho evitasse a primeira bebida a ele oferecida, como suspeita de conter veneno, e que o pai assim enganado, logo no princípio do banquete, dera a Druso a taça recebida, e tendo ele sem desconfiança e inconsideradamente bebido, deu força à suspeita, parecendo que por medo ou vergonha voltasse contra si o atentado que preparara para o pai. Isto se disse entre o vulgo, mas não foi confirmado por nenhum autor fidedigno e facilmente podem refutá-lo, pois ninguém de medíocre bom senso, quanto mais Tibério, tão atilado e experiente, daria por sua própria mão a morte ao filho sem primeiro ouvi-lo, cortando de um golpe toda a possibilidade de arrependimento. Poria antes a tratos o portador do veneno, indagaria o autor do crime, e então que se tratava de seu único filho, nunca dantes suspeitado de culpa, usaria de sua natural contemporização, praticada até com os estranhos. Mas como 
Sejano era tido por maquinador de todos os atentados por causa de sua íntima ligação com César e o ódio geral contra ambos, adquiriram crédito os rumores mais fantásticos e monstruosos, acrescendo ainda que a voz pública é sempre cruel para explicar a morte dos poderosos. Mas o plano do crime foi depois exposto por Apicata, esposa de Sejano, e comprovado por Eudemo e Ligdo submetidos a torturas; e nenhum dos historiadores que tudo perquiriram e exageraram, houve tão inimigo de Tibério que o culpasse. Este rumor eu lembro e refuto somente para condenar com um exemplo claro as falsas atoardas e pedir àqueles a cujas mãos chegar este nosso trabalho, que às narrações verídicas e simples nunca prefiram histórias extranaturais, avidamente aceitas pelo vulgo. (Ann., IV, 10-11)

Tácito inicia contrastando o rumor, uma tradição oral ainda persistente na época em que escreve, com uma tradição escrita. Diz desta última que, por ter sido transmitida por muitos autores de máxima credibilidade, era a mais digna de confiança, tanto que a seguiu em sua própria narrativa. Segundo esta versão, o eunuco Ligdo teria envenenado diretamente Druso, a mando de Sejano, chefe da guarda pretoriana e homem próximo ao imperador (Ann., IV , 8). Contudo, a permanência de um rumor, incluindo Tibério no assassinato, requeria exame a fim de rejeitá-lo como fonte digna sobre um fato passado, pois derivada do vulgo. Tácito, então, no intuito de provar sua falsidade, procura demonstrar que tal tradição baseia-se em indícios equivocados. Em primeiro lugar, afirma que reflete uma ignorância a respeito da personalidade de Tibério. Colocando-se como conhecedor deste detalhe, Tácito argumenta que a natureza do imperador não lhe permitiria agir da maneira que o rumor supõe. Além do mais, a culpa de Sejano foi testemunhada por sua própria mulher e, sob tortura, pelos eunucos envolvidos. Como indício conclusivo afirma que a inocência de Tibério é atestada até por aqueles historiadores que eram contrários ao imperador e que, portanto, estariam inclinados a denegrir sua imagem.

Tácito, com esta inquirição, demonstra ao leitor que não aceita de imediato qualquer tradição, sem antes colocá-la à prova. Já a opinião do vulgo repousa em uma falsa indução, corroborada pelo viés parcial que tem do episódio. Da proximidade entre Sejano e Tibério deduziu-se a cumplicidade do imperador no crime, versão construída e propagada 
devido ao ódio que muitos votavam a estes personagens. Esta tradição, por sua vez, perpetuou-se, apoiada no errôneo senso comum, que, voltado para o fabuloso, tende a descrever de forma cruel toda morte de indivíduos poderosos.

Em contraposição a este raciocínio, antes fundado na crença do que na ponderação crítica, Tácito firma o método de sua narrativa histórica e a autoridade da mesma, pois transmite apenas o que é consensual entre os escritores consultados e não é afeito a versões fabulosas, falsas por sua parcialidade e deficiente saber. A utilidade de sua narrativa revela-se assim por indicar a seus leitores um outro modo de pensar que o do vulgo, pois, como bem observou Patrick Sinclair, o uso por Tácito da primeira pessoa do plural ao final do episódio (nosso trabalho) estabelece uma comunidade de pensamento entre o historiador e seu público. ${ }^{5}$

Apesar de Tácito enfatizar que se deteve no episódio acima para ilustrar seu método inquiritivo, sugerindo assim a permanência deste no restante da obra, é comum lermos na crítica moderna indagações sobre a pequena quantidade de semelhantes observações metodológicas por parte do historiador (Shatzman, 1974, p. 551). De fato, nos Anais, menções sobre a concordância, ou não, em relação às fontes utilizadas são numericamente escassas tendo em vista a extensão da obra; em apenas dois episódios, excetuando-se o acima analisado, Tácito se detém na crítica à parcialidade dos historiadores que o precederam. Assim, no episódio da morte de Popéia, esposa de Nero, escreve:

Depois de terminados os jogos, morreu Popéia, vítima de fortuita irascibilidade de seu esposo que a atingira com um pontapé, estando ela grávida. Não creio tivesse morrido envenenada, embora alguns historiadores narrem, pois acho que assim o fizeram, levados mais pelo ódio que pela verdade, porquanto Nero desejava muito ter filhos e vivia dominado pelo amor de sua mulher. (Ann., XVI, p. 6)

Tácito comenta neste trecho como a parcialidade dos historiadores deturpa a verdade de um acontecimento histórico. No seu entendimento, o ódio dos escritores com relação a Nero fez com que transmitissem uma versão da morte de Popéia desfavorável ao imperador, ou seja, a de que voluntariamente a perpetrou pelo veneno. Diz que esta 
tese é inverossímil, pois Nero desejava ter filhos e amava sua mulher e, portanto, apenas um acesso de cólera poderia explicar seu comportamento.

Ainda com respeito à questão da parcialidade, contrasta as versões sobre a reação de Nero diante de um suposto envolvimento em uma conspiração do prefeito da guarda pretoriana, Afrânio Burro:

Conta Fábio Rústico ter sido enviada por escrito a Cecina Tusco uma ordem para que assumisse o comando das coortes pretorianas, e que só por conselho de Sêneca fora Burro conservado. Plínio e Clúvio referem que nenhuma suspeita pairou sobre a lealdade do prefeito. É verdade que Fábio tende a louvar Sêneca, pois ascendeu por sua amizade. É meu costume seguir a unanimidade dos historiadores e, quando divergem, narrar os fatos sob a autoridade de cada um com a citação de seus nomes. (Ann., XIII, 20)

Tácito lança dúvidas sobre a versão de Fábio Rústico pela ligação pessoal que ele possuía com Sêneca, o que poderia tê-lo incitado a introduzir na narrativa uma provável interferência do filósofo a fim de elogiá-lo. Finaliza com uma observação metodológica que, nos Anais, aparece aplicada apenas uma vez, quando comenta sobre um provável incesto entre Nero e sua mãe, Agripina (Ann., XIV, 2) (SinclaIr, 1995, p. 76).

Todavia, estes raros comentários inseridos na narrativa taciteana, ao invés de serem interpretados como uma deficiência metodológica, devem ser compreendidos como uma estratégia retórica que visa confirmar precisamente a excelência da narrativa, confirmando sua credibilidade e autoridade. Revelariam que Tácito superou o obstáculo colocado pela parcialidade das versões que recolheu, compondo uma narrativa uniforme e veraz. Esta postura do historiador é esclarecida mediante um paralelo com a leitura do célebre discurso de Caio Cássio, sobre o assassinato do prefeito da cidade de Roma por um de seus escravos em 61 d.C. Esta comparação permite-nos sugerir uma explicação sobre o silêncio metodológico taciteano no contexto da elaboração retórica de sua obra.

Eis o contexto do discurso. Segundo Tácito, em 61 d.C., o prefeito da cidade de Roma, Pedânio Secundo, foi morto em casa por um de 
seus escravos. As razões apontadas foram duas: ou o senhor recusara a liberdade ao escravo após já ter combinado o preço, ou rivalizavam pelo amor de um rapaz (Ann., XIV, 42, 1). A pena prevista em lei para uma ocorrência deste tipo previa a execução de todos os demais escravos que estivessem na casa no momento do crime. Como eram 400 no total, houve uma comoção tanto dentro do Senado como entre a plebe. Seguiuse, então, um discurso do senador C. Cássio Longino, defendendo a aplicação da pena:

Muitas vezes, padres conscritos, fui presente a esta assembléia em ocasiões em que se pedia revogação de leis e práticas instituídas por nossos maiores, e não fui contrário, não porque duvidasse que sobre todos os negócios eles soubessem prover melhor e com mais acerto e que as inovações costumam ser prejudiciais, mas apenas para não parecer que, por muito amor aos costumes passados, estivesse eu a fazer ostentação de meus estudos. Ao mesmo tempo julgava que não devia diminuir, em freqüentes contestações, a pouca autoridade que tivessem minhas opiniões, reservando-a para momentos em que minha colaboração pudesse ser útil ao estado. É isto que hoje acontece. Um varão consular é morto em sua casa por um escravo: não houve quem denunciasse ou impedisse a perpetração do crime, sabido, como é, que por um senatus-consulto é cominado o suplício a toda a família. (Ann., XIV, 43, 1-3)

O orador inicia explicando as suas poucas intervenções na arena política e a razão de sua manifestação no presente caso. Diz que mesmo sendo de opinião contrária à daqueles que defendem a reforma da legislação promulgada pelos ancestrais evitava seus protestos por dois motivos. Em primeiro lugar, para não parecer que suas manifestações tivessem por objetivo a sua mera promoção individual, ou seja, a utilização do senado como palco para exibição de seus conhecimentos jurídicos, sua área de estudos (Ann., XII, 12). O segundo motivo revelado pelo orador é ainda mais relevante. Diz que evitou freqüentes intervenções para não abalar sua autoridade, preservando-a para questões oportunas e que lhe parecessem fundamentais para o Estado. A autoridade é, assim, entendida como eficaz e persuasiva quando explicitada esporádica e calculadamente. Quando a ocasião se apresenta justifica-se a interven- 
ção, a qual, contudo, deve revelar uma capacidade crítica de análise do caso em debate. O orador demonstra isto ao rebater as alegações dos que eram contrários à execução de todos os escravos:

Se tivéssemos de deliberar agora pela primeira vez acerca de um caso igual, credes vós que um escravo conceberia o plano de matar seu senhor, sem deixar escapar uma palavra de ameaça ou não caísse em alguma leviandade? Suponhamos que teve a maior discrição e conseguiu trazer ocultamente a arma: mas, ainda assim, como iludir as sentinelas, abrir a porta do quarto, levar luz, cometer o crime, sem que ninguém o soubesse? Muitos indícios antecedem aos crimes (Ann., XIV, 44, 1-3).

O orador para refutar a versão de seus oponentes elenca indícios que comprovem que o escravo não poderia ter agido sozinho. Reconstitui o fato passado, o assassinato, argumentando sobre a impossibilidade de uma ação isolada do escravo. Como se vê, igual procedimento utiliza Tácito na demonstração da falta de coerência de certas tradições históricas, pois o historiador contrapõe a estas os indícios que julga convincentes para a reconstituição do fato histórico.

Assim como a inquirição do passado pelo historiador tem por objetivo formular um esquema cognitivo, uma forma de pensar, para seus leitores, tal como exemplifica o episódio da morte de Druso, o orador também visa esta finalidade, conforme demonstra a parte final do discurso de Cássio:

Caso os escravos denunciem, podemos ser poucos dentre muitos, todos eles estando inquietos; enfim, se tivermos que perder a vida, os culpados não ficarão impunes. Nossos antepassados não confiavam na lealdade dos escravos, ainda mesmo dos nascidos em suas propriedades e em suas casas, criados no afeto dos senhores. Hoje que temos em nossas famílias servis pessoas de nações diversas, de vários ritos, de religiōes diferentes ou de nenhuma, só medo pode ser coerção para esse entulho. Objetarse-á que muitos morrerão inocentes. Sim, mas quando se dizima um exército e cada décimo soldado é castigado, a sorte cai também sobre os valorosos. Todos os grandes exemplos trazem consigo alguma iniquidade contra indivíduos, porém esta redunda em utilidade pública. (Ann., XIV, 44) 
$\mathrm{Da}$ argumentação sobre indícios particulares, restritos ao contexto da morte do prefeito, Cássio passou a uma de caráter mais geral. Transforma o extermínio de todos os escravos em um exemplo a ser sempre seguido em ocasiões semelhantes. Como a desconfiança é inerente à relação escravista, sejam os escravos nascidos no espaço doméstico sejam oriundos de terras estrangeiras, a estratégia de controle a ser legitimada é a da promoção do medo, argumento que encontra justificação em uma sententia: todos os grandes exemplos trazem consigo alguma iniquidade contra indivíduos, porém esta redunda em utilidade pública. A transcendência desta conclusão para o episódio em questão já é, aliás, percebida na comparação entre escravos e soldados, mas tal sententia também encerra uma forma de pensar a intervenção estatal na sociedade. Como demonstrou Heinz Bellen, a fórmula do discurso de Cássio remete a um dos princípios programáticos do principado, segundo o qual a utilitas publica deve prevalecer sobre a utilitas singulorum (MARTIN, 1994, p. 200; Von Albrecht, 1995, p. 1107). ${ }^{6}$ Cássio conclui seu discurso com uma orientação política para o presente (SCHELLHASE, 1976, p. 142). ${ }^{7}$

Portanto, orador e historiador adotam uma similar metodologia, sugerindo uma aproximação entre retórica e história. A investigação do passado a partir de uma argumentação fundada em indícios prováveis visa estabelecer a verdade, não somente para esclarecer o próprio passado, mas também, e principalmente, os parâmetros de intervenção no presente. Esta teleologia da narrativa taciteana é detalhada em uma digressão no livro IV dos Anais.

O presente passado: a crítica sócio-política na narrativa histórica

Esta digressão estrutura-se a partir de um contraste com a historiografia republicana e pode ser dividida em duas partes. Uma primeira parte versa sobre a axiologia histórica e sua relação com a glória do historiador (Ann., IV, 32). A segunda parte (Ann., IV, 33) trata da teleologia histórica, respectivamente, da história enquanto pedagogia ética e da função hedonística da narrativa histórica.

Na primeira parte (Ann., IV, 32), Tácito esclarece a axiologia de sua narrativa. Ao contrário da historiografia republicana que tem a seu dispor feitos grandiosos (no plano externo, guerras, conquistas de cidades, 
morte e captura de reis; em Roma, conflitos políticos entre a plebe, ou seus representantes (tribunos da plebe) e a aristocracia), ele, Tácito, apresenta apenas feitos menores, insignificantes mesmo, se comparados aos de seus predecessores, pois predomina a paz e não a guerra e apenas fatos tristes na cidade, como os já mencionados. Ao discorrer sobre tal seletividade, Tácito, portanto, relaciona sistema político e atividade historiográfica. As possibilidades de o historiador almejar a glória com sua narrativa são diretamente proporcionais ao grau de conflito políticos e belicosos proporcionado pelo sistema político vigente. Deste ponto de vista, o Principado é diametralmente oposto à República, logo, cabendo pouca glória a Tácito.

Todavia, ao final desta argumentação Tácito reverte esta negatividade da restrição axiológica, apontando para um aspecto positivo da mesma, o deslocamento que faz para a questão da utilidade da história:

Contudo não terá sido sem utilidade perscrutar aqueles feitos aparentemente insignificantes a partir dos quais muitas vezes o motivo de grandes feitos tem origem. Todas as nações e cidades são regidas ou pelo povo ou pelos principais cidadãos ou por um só. Uma forma de governo escolhida e composta a partir destas é mais fácil de ser louvada do que produzida, ou, caso venha a ser, não pode ser duradoura. Pois então que a plebe era forte, que os senadores tinham poder, deviam ser conhecidas a natureza do vulgo e por quais modos, com moderação, fosse tratado; os que sabiam com perfeição o caráter dos senadores e principais cidadãos, eram considerados experientes e conhecedores dos tempos. Como na situação inversa Roma não é outra coisa que se um imperasse, esta busca e transmissão terá sido de interesse, pois poucos por prudência as coisas honestas das más, as úteis das prejudiciais discernem, a maioria é ensinada pelo que acontece aos outros. (Ann., IV, 33, 1-2)

Assim como a respeito da axiologia da narrativa histórica, Tácito estabelece uma conexão entre historiografia e regime político. A atividade do historiador é determinada pelo regime político que lhe é contemporâneo, na medida em que este traça os limites epistemológicos que conformam a narrativa histórica. Esta deve se adaptar à vigente distribuição do poder político. Neste sentido, Tácito inicia descartando a teoria da constituição mista de governo - a combinação de democracia, aristocracia e monarquia 
- como um modelo político que deva ser incorporado pela narrativa histórica (Bellen, 1982, p. 454-455; GABBA, 1995, p. 333ss). ${ }^{8}$ Não é factível, embora louvável. Também descarta o modelo republicano, fundado na existência do povo e do senado como agentes políticos. No principado, diz Tácito, estes grupos não mais estão no centro do campo político, agora monopolizado pelo imperador. Ciente desta ruptura, o historiador defende uma narrativa compatível com o regime imperial, tendo por função a transmissão de preceitos para a conduta nesse regime.

Com esta argumentação, Tácito formula a teleologia de sua obra. Ao historiador cabe fornecer a seus leitores ações de personagens históricos que primam tanto pela grandeza positiva quanto pela negativa, a fim de que tenham referenciais para suas próprias ações. Ao elencar exemplos de conduta que sejam malignos e prejudiciais, espera que o leitor adote a postura contrária, o caminho do bom e do honesto.

Por sua vez, ao traçar como limites conceituais de sua teleologia histórica as categorias éticas do útil e do honesto, Tácito alinha-se com o pensamento filosófico da Nova Academia e seu desdobramento na retórica. Filiação já esboçada nos termos em que, no Diálogo dos oradores, apresenta a relação entre retórica e verdade. No discurso do orador Messalla, que faz a apologia da retórica ciceroniana, é proclamada como função do orador praticar, no fórum, uma "verdadeira eloquência" (uera eloquentia, Dial., 34, 4), ao contrário do que ocorre nas escolas de retórica onde as declamações versam sobre casos fictícios, que se afastam da verdade (abhorrenti a ueritate, Dial., 35, 4). Daí o orador objetivar a verdade através do seguinte processo:

Examinar o que é bom e mau, honesto e torpe, justo e injusto; esta é a matéria que cabe ao orador dissertar. Pois nos discursos judiciários normalmente sobre a eqüidade, nos deliberativos sobre a utilidade, nos elogios sobre a honestidade dissertamos. (Dial., $31,1-2)$

Estabelecer a verdade é dever do orador, através do tratamento do que é útil e honesto e da eqüidade entre estes conceitos. A verdade é assim uma categoria dependente do juízo crítico do orador no contexto da causa que está a defender. Similar esquema aplica-se ao historiador, como sugere a digressão dos Anais, pois este, tomando como ponto a defender a inevitabilidade do Principado, também pondera sobre as ações 
humanas passadas - úteis, honestas e seus opostos - a fim de indicar, a partir de seu julgamento, um conhecimento a seus leitores, orientandoos no plano ético presente.

No entanto, desta redefinição da utilidade da história Tácito extrai duas consequiências. Por um lado, a diminuição da função hedonística da narrativa histórica. Por outro, a conjunção de temporalidades que sua narrativa opera ao pressupor que seus leitores traçam paralelos entre o presente e o passado. Estas duas consequiências são expostas na parte final da digressão em que a redução axiológica é aqui tratada do ponto de vista do público leitor:

Logo, estas coisas devem ser de proveito, ainda que tragam o mínimo de deleite: pois a situação de povos, variedades de combates, ilustres mortes de chefes retêm e restauram a disposição dos que lêem. Nós, ordens cruéis, acusações consecutivas, amizades falazes, a ruína de inocentes e mesmas causas de seus fins, fatos óbvios quanto à semelhança e à quantidade. Então para os antigos escritores não havia um raro detrator, e nem interessava qual dos exércitos, púnicos ou romanos, com mais ardor tivesse elevado. Mas de muitos que de Tibério, enquanto reinava, sofreram punição ou infâmias, permanecem descendentes. Mesmo que as próprias famílias já estejam extintas, encontrarás os que pela semelhança dos costumes julgam os maus feitos alheios imputados a si. Até para a glória e o que é virtuoso há inimigos, pois parecem condenar ações contrárias quando a elas comparadas.

Se para o historiador há uma diminuição de sua glória, para o público, significa uma perda de prazer na leitura da narrativa histórica (ChiappetTA, 1997, p. 138). Sendo um de seus objetivos entreter pela variedade factual, esta é negada pelo relato de eventos similares, o que, contudo, como vimos, é justificado pela utilidade que a história adquire como manancial de exemplos. Outro impedimento à realização da função hedonística é, diz Tácito, a permanência de indivíduos com vínculos familiares no passado. A transmissão da memória de feitos dos antepassados que não comportam distinção positiva repercute no presente, tempo de seus descendentes. Além desta, outra categoria de conjunção de temporalidades presente e passada é indicada por Tácito como fator de 
repulsa da narrativa por seus leitores. Mesmo aqueles que não têm vínculos familiares com o passado, rejeitam a obra do historiador por empreenderem uma leitura especular da mesma, ou seja, comparam-se com personagens históricos de comportamentos similares. Ao realizarem esta operação cognitiva entendem a narrativa como uma fonte de críticas indiretas a si próprios. A narrativa do passado apresenta-se, portanto, como uma reelaboração discursiva a partir do presente, ou seja, os agentes históricos retratados pelo historiador remetem a tipos sociais de validade atemporal.

De fato, um dos recursos retóricos mais freqüentes nos Anais é a criação de estereótipos a partir de descrições de indivíduos determinados. Um caso paradigmático desta metodologia é o da figura do delator:

Pouco tempo depois Cépio Crispino, questor de Grânio Marcelo, pretor da Bitínia, fez contra este acusação de lesa-majestade, de comum acordo com Romano Hipo; e foi assim que ele criou uma forma de vida que depois a miséria dos tempos e a audácia dos homens tornaram vulgar. Pobre, desconhecido, irrequieto, insinuando-se por libelos secretos na maldade dos príncipes, pondo em risco homens ilustres, conseguindo influência junto a um, mas a odiosidade de todos, deu o exemplo, que seguiram muitos, de pobres tornados ricos, de desprezados, temidos, cavando a perdição dos outros e a sua própria. (Ann., I, 74)

Os delatores são apresentados como almejando exclusivamente a ascensão social, e a sententia que sintetiza esta estratégia é que perecem pelos próprios meios que utilizam para avançar. Observe-se que no texto acima não interessa a Tácito as personalidades individuais tanto que não esclarece a quem se refere o pronome "ele" (Cépio ou Hipo?) que inicia a caracterização do delator. A preocupação de Tácito é a de ressaltar que tais indivíduos históricos personificam uma "forma de vida" (formam uitae), um "exemplo" (exemplum) (LucE, 1993, p. 13). ${ }^{9}$ A generalização indutiva a partir da menção de uma realidade passada é, portanto, um recurso retórico de Tácito que funda seu pensamento político na empiria histórica.

Esta dualidade da narrativa taciteana - afirmar como teleologia a crítica do presente por meio de sua sobreposição com o passado e, ao fazê-lo, abrir espaço para uma reação negativa de determinado público 
- encontra, por seu turno, um paralelo na apresentação que faz Tácito da teleologia poética no Diálogo dos oradores.

\section{O Diálogo dos oradores e a teleologia poética}

Apesar de o tema declarado desta obra ser o declínio da eloqüência (WoOdman \& Kraus, 1997, p. 93), é a poesia, mais do que a própria oratória, o centro do debate entre os interlocutore ${ }^{10}$ (SINCLAIR, 1995, p. 11-12). A questão da oratória emerge apenas, e como que acidentalmente, a partir da discussão sobre uma tragédia recitada por Curiátio Materno (Syme, 1967, app. 90). Tácito situa temporalmente o diálogo no dia seguinte à recitação:

No dia seguinte a que Curiátio Materno recitou seu Catão, o qual, dizia-se, tinha ofendido o ânimo de poderosos, pois nesta tragédia cogitava-se que havia misturado seus argumentos com os de Catão, sendo isto por toda cidade motivo de conversas, Materno recebeu a visita de Marco Aper e Júlio Secundo, então os mais renomados talentos de nosso fórum. (Dial., 2,1)

Com esta cena inaugural Tácito introduz o tema que será objeto da discussão entre Secundo, Aper e Materno, a saber, a questão da interpretação da tragédia no que se refere à identidade entre poeta e personagem trágico:

Secundo lhe disse: "Não te causam medo, Materno, as estórias que propagam as más pessoas, pois, apesar das ofensas, amas teu Catão? Ou, por ventura, pegaste este livro, para revisá-lo com diligência, e suprimido o que possa dar azo a interpretações disformes, publicar não um Catão melhor, porém mais seguro?" Então ele: "Lerás o que Materno pretendia, e compreenderás o que ouvir. Se Catão omitiu algo, na recitação seguinte Tiestes o dirá, pois esta tragédia já esbocei e compus em minha mente. Se me apresso a acabar a edição deste livro, é para me liberar por inteiro para o outro trabalho."

"Logo não te saciastes destas tragédias", replicou Aper, "que, negligenciando o estudo dos discursos causídicos, dedique tempo então a Medéia, agora a Tiestes, enquanto as causas dos amigos, a clientela das colônias e municípios te chamam ao fórum, 
os quais dificilmente apoiarias, ainda que não tivesses outro negócio, como um Domício ou um Catão, isto é, nossas histórias e nomes romanos combinas com estórias gregas." (Dial., 3, 2-4)

Secundo inicia exortando Materno a modificar o conteúdo da tragédia na sua versão escrita, pois a recitação oral havia gerado interpretações distorcidas, ou seja, determinados indivíduos a consideraram como uma ofensa a si próprios. Isto porque entenderam a tragédia como uma forma discursiva das opiniões pessoais do poeta. A resposta de Materno concorda com esta constatação, mas anuncia sua intenção de prosseguir na atividade poética. Diz ele que pouco importa o personagem, Catão ou Tiestes, dirá o que pensa. A intervenção de Aper aprofunda esta questão da identidade entre poeta e personagem considerando-a a partir da relação temporal nela implícita. Comparando a tragédia com a oratória judiciária, caracteriza a primeira segundo a temporalidade de seus temas: personagens históricos de um passado distante, a República romana, ou de um tempo mítico. O orador, pelo contrário, versa sobre indivíduos que lhe são contemporâneos e com quem mantém relações sociais, sejam de amizade, sejam de patronato.

Tácito estabelece, portanto, uma contraposição entre orador e poeta segundo a temporalidade do objeto tratado por ambos. Enquanto o primeiro disserta sobre indivíduos com existência presente, o segundo trata de personagens sem manifestação fenomênica neste tempo. Este contraste determina o modo de recepção pelo público da tragédia e da oratória, como demonstra o final do discurso de Aper a Materno, no qual defende a utilidade da oratória:

Transborda a força de sua admirável natureza, não para causar ofensa por um amigo, mas por Catão, o que é mais perigoso. Não pode se desculpar pelas obrigações do ofício, pela lealdade de advogado, ou pelo ímpeto de um falar inesperado e fortuito. Parece que escolheu com meditação um personagem notável e com discurso de autoridade. Sei o que podes responder: que ele causa entusiasmo, sendo aplaudido pelos que freqüientam as leituras e logo todos estão a comentá-lo. Mas esqueça este pretexto de isolamento e segurança, pois procuras um adversário que é superior a ti. Que a nós seja suficiente atuar em causas particulares e deste século, nas quais se for preciso ofender os ouvidos de 
poderosos por um amigo em perigo, que a lealdade seja aceita e a liberdade justificada. (Dial., 10, 5-8)

A exortação de Aper inicia com a constatação de que o discurso poético é mais propício a causar uma reação negativa no público do que o discurso judiciário. Neste, possíveis ofensas podem ser justificadas pelo comprometimento profissional do orador com seu cliente. Por tratar de questões contemporâneas que envolvem indivíduos particulares, a oratória judiciária abre espaço para retratação. Para o poeta, todavia, não cabe uma tal justificativa. $O$ personagem que escolhe não existe enquanto indivíduo, mas é atualizado pelo poeta na representação trágica. Não por acaso Aper afirma que Materno escolheu Catão, uma pessoa (persona) de notabilidade e autoridade de discurso. Como se sabe, persona, em seu sentido original, é a máscara que usa o ator teatral. Catão é precisamente isto para Materno, uma máscara que o poeta usa para expressar suas opiniões pessoais. Ele não fala por outrem, como o orador, mas por si. Esta identificação da figura do poeta com a de seu personagem é decorrência justamente de a tragédia, ao contrário da oratória, ser um discurso que não remete a indivíduos particularizados do presente, mas revestir-se de um caráter atemporal. Característica, contudo, que the permite ser um instrumento de crítica deste mesmo presente.

Esta conjunção de passado (histórico ou mítico) e presente conforma assim a teleologia trágica e remete a uma semelhança com a teleologia da narrativa histórica, tal como formulada por Tácito na digressão do livro IV dos Anais. Ambos os discursos surtem um efeito sobre o público pela crítica indireta, inserida na representação de uma realidade passada. Este paralelo entre o agir do historiador e do poeta é ainda ressaltado no discurso com que Materno responde a Aper, negando a inutilidade da poesia. Ao final exclama: "Feliz aquele outro, e para falar do nosso modo, século áureo ${ }^{11}$ (HeחlmanN, 1989, p. 390) que, ausente de oradores e crimes, abundava em poetas e oráculos, que cantavam os bons atos e não defendiam os maus perpetrados" (Dial., 12, 3).

Aludindo a um passado mítico Materno deriva as categorias adequadas para o tempo presente, histórico. Esta tarefa do poeta, a de cantar os bons feitos e não defender os maus, como observou Willibald Heilmann, "leva-nos a pensar no Tácito historiador. Para o poeta como 
para o historiador, o objetivo de seus trabalhos é o conhecimento das condutas corretas, o que Tácito entende por rectum, isto é, honestum". Também significativo é o fato de Tácito encerrar o Diálogo com um discurso de Materno cujo conteúdo é similar ao que ele apresenta na digressão dos Anais: o reconhecimento da inevitabilidade do Principado e a conseqüente necessidade de adequação a ele.

O discurso inicia com a afirmação de que a eloqüência republicana é discípula da licença (est magna illa et notabilis eloquentia alumna licentia, Dial., 40, 2), fundada em um regime político sem direção:

Também nossa cidade, então errante, com facções, dissensões e discórdias a consumindo, nenhuma paz no fórum, nem consenso no senado, nem regras diante do tribunal, nem respeito aos superiores, nem limites aos magistrados, produzia, sem dúvida, uma eloqüência vigorosa. (Dial., 40,4)

O conflito é o material da eloqüência, mas o custo político disto é um Estado instável. ${ }^{12}$ Sendo o Principado o reflexo invertido da República (HeLlmANN, 1989, p. 389), ele deve ser aceito, e daí o conselho que Materno dirige aos presentes na conclusão de seu discurso:

Acreditem, grandes homens e hábeis no falar, se vós nos séculos anteriores ou aqueles homens, aos quais nos voltamos, neste século tivessem nascido, e um deus mudasse os períodos de vossa vida, nem a vós teriam faltado aquele sumo louvor e glória na eloqüência nem àqueles medida e temperamento; contudo, já que ninguém pode, ao mesmo tempo, obter grande renome e tranqüilidade, o seu bom século quem quer que seja pode aproveitar, sem denegrimento dos outros. (Dial., 41,5)

Parafraseando Horácio, ${ }^{13}$ Materno nega a possibilidade da coexistência, dentro de uma mesma forma de governo, de conflitos políticos e estabilidade estatal (ninguém pode, ao mesmo tempo, obter grande renome e tranqüilidade). Optando por esta última, Materno apregoa a necessidade de aceitação do Principado mesmo que este tenha como efeito perverso a eliminação da glória do orador. Em linhas gerais, é a mesma argumentação de Tácito, nos Anais, com relação à escrita da história. Os conflitos da República romana permitiram ao historiador 
obter glória. Mas o principado, ao promover a paz política, encerrou este quadro, redirecionando a função da história para a indicação de uma ética de participação neste regime.

Portanto, podemos dizer que da poesia (em particular, a tragédia) a história taciteana herda seu princípio teleológico de crítica do presente por meio da comparação com o passado, porém com uma diferença: não mais o passado republicano é seu parâmetro, mas o passado imperial. ${ }^{22}$ Escrevendo seus Anais na primeira metade do século II, Tácito remete ao principado júlio-cláudio elaborando um espelho crítico de sua realidade contemporânea.

\section{Abstract}

This article analyses Tacitus' conception of historical truth in the Annales and its relations with tragedy as discussed by him in the Dialogus de oratoribus.

Key words: Historiography, truth, poetics, Tacitus.

\section{Notas}

1. Esta perspectiva, apresentada na forma de uma oposição entre Tácito historiador e Tácito escritor, é encontrada em muitos estudiosos. Contudo, é no uso que faz Max Weber (1996) da expressão taciteana sine ira et studio que encontramos o melhor exemplo de como ela foi erigida em sinônimo de impessoalidade e imparcialidade.

2. Também o termo imperium comporta uma dupla leitura. Termo ambíguo devido à sua diversidade semântica, imperium tanto designa as competências legais ordinárias das magistraturas romanas como denomina um poder de cunho pessoal, a dominação exercida por um indivíduo (BÉRANGER, 1977, p. 332,334). Deste modo, ao referir-se ao poder de Augusto tão somente com esta palavra Tácito sintetiza no principado aquela dicotomia legalidade e ilegalidade que perpassa a arqueologia.

3. É difícil precisar a quais autores Tácito se refere pois da historiografia imperial pouco se preservou. Porém, é possível contextualizar a sua crítica à história como elogio, tomando como referência a História Romana, de Veleio Patérculo, ao que tudo indica, uma das fontes consultadas por Tácito. 
Nesta obra, que chegou a nós incompleta, Veleio freqüentemente insere informações sobre si e sua família (MARINCOLA, 1997, p. 143). Homo nouus, oriundo de uma aristocracia municipal, da Campânia, faz questão de marcar as etapas de sua promoção social e política pelo imperador, de modo que entrelaça sua história de vida com a do principado. Memorando, por exemplo, a campanha de Caio César na Síria e seu encontro com o rei dos partas, escreve: "Nesta missão, sua conduta foi tão variada que oferece material abundante para seu elogio, escasso para seu vitupério. Teve um encontro com o rei dos partas, um jovem excelentíssimo, em uma ilha do Eufrates, sendo igual de ambas as partes os cortejos. Este espetáculo esplêndido de dois exércitos face a face, o dos romanos de um lado, o dos partas de outro, enquanto se encontravam os dois eminentes chefes que dominavam os impérios e homens, me foi possível contemplar (uisere) ao começo de minha carreira como tribuno militar" (101, 1-2).

O historiador tem credibilidade pelo fato de narrar o que viu pois era um personagem próximo ao imperador e subordinado a este, já que exercia um cargo no exército. Esta sua posição interfere na maneira como seleciona a memória a ser transmitida por sua narrativa. Apesar de dizer no início que também havia material para criticar a conduta de Caio, não o usa, privilegiando o que the confere elogio, o que enfatiza o lado positivo das ações imperiais.

4. O distanciamento que Tácito advoga ao final do proêmio com a expressão sine ira et studio, segundo A. Dihle (1971, p. 32), é uma apropriação da idéia epicurista segundo a qual a posição divina diante da sociedade humana é de chôris orgés kai cháritos.

5. Per uulgum, cui minor sapientia, Ann., 14, 60; neque illis (i. e. plebs) iudicium aut ueritas, quippe eodem die diuersa pari certamine postulaturis, Hist., 1, 32 (Shatzman, 1974, p. 552).

6. Já no século XVI, Scipione Ammirato, poeta e genealogista de Lecce, chamava a atenção para a relevância política desta máxima taciteana. Nos seus Discorsi sopra Cornelio Tacito, obra publicada em 1594, relacionavaa à idéia de "razão de Estado" (SChellhaSe, 1976, p. 142).

7. A qual, aliás, já fora delineada no início de sua fala. Sua intervenção no senado visava não um interesse particular, sua mera promoção social, mas o interesse do Estado.

8. Tácito expõe aqui a tripartição ciceroniana dos genera dicendi e os respectivos conceitos éticos que abordam, como se depreende a partir de uma análise conjugada do De officiis e das Partitiones Oratoriae. Como demonstrou Angélica Chiappetta, "os deveres relativos ao honesto 
aparecem no livro I, do De officiis, divididos em quatro partes: o conhecimento do verdadeiro, a manutenção da sociedade entre os homens, a formação de um ânimo robusto e a conveniência no agir e no dizer. Destas quatro partes, sai o material para o elogio e o vitupério. Ao tomar uma decisão, objetivo do discurso deliberativo, o fim observado deve ser a utilidade, discutida no livro II do De officiis. Já no discurso judiciário, o fim a ser observado é a equidade, presente no livro III, do De officiis" (CHIAPPETTA, 1997, p. 138).

9. Conforme o proêmio: Saepe ex me requiris, Iuste Fabi, cum priora saecula tot eminentium oratorum ingeniis gloriaque floruerint, nostra potissimum aetas deserta et laude eloquentia orbata uix nomen ipsum oratoris retineat, Dial., I, 1. O declínio da eloquência é, aliás, um topos da literatura imperial: Veleio Patérculo (1,16-18), Sêneca, o Velho (Controuersia 1, praef. 6-10), Petrônio (88, 1-2), Sêneca (Epistulae 114, 1-2), Plínio, o Velho (Naturalis Historia, 14, 1, 3-7), Quintiliano (Institutio Oratoria, 8, 6, 76), Plínio, o Jovem (Epistulae, 2, 14) (cf. LuCE, 1993, p. 13).

10. Quatro são os interlocutores: Curiátio Materno, Marcos Aper, Júlio Secundo e Vipstânio Messalla. Sobre o primeiro pouco se sabe. É certo que era um senador, mas sua origem é duvidosa (ver Syme, 1967, app. 90).

11. A expressão "século áureo" (aureum saeculum) é uma alusão a Virgílio, à idade de ouro sob o reinado de Saturno, como aparece nas Geórgicas (II, 532-540), cf. Heilmann, 1989, p. 390.

12. Materno retoma argumentos do discurso precedente de Secundo. Este explica o declínio da eloquência como resultado do estabelecimento do Principado. Segundo ele, a República caracterizou-se por ter sido um período de perturbatio e licentia, o que contribuía com material para o orador (Dial., 36, 3). Na ausência de um indivíduo moderador (cum...moderatore uno carentibus, Dial., 36, 2, ou seja, a falta de um imperador), era o orador quem persuadia o povo errante (erranti populo persuaderi poterat, 36, 2), dirigindo a ele e também ao Senado (cf. Dial., 36, 5: cum et populum et senatum consilio et auctoritate regerent). Disto decorria o acúmulo de honras (Dial., 36,4) e aumento de influência (Dial., 36, 4). Secundo reconhece que o regime instaurado por Augusto, ao estabelecer a paz (Dial., 38, 2), acarretou o declínio da eloquência, mas afirma que foi melhor assim, pois restabeleceu a ordem (Dial., 37, 5).

13. Cf. Dial., 41, 4: "Por que dissertar longamente no senado, se os melhores logo chegam a um consenso? Para que muitos discursos diante do povo, se sobre o Estado não muitos imperitos deliberam, mas aquele que é o mais sábio [i. e. imperador]?". 


\section{:ferências}

BRION, Etienne. L'historien Tacite face à l'évolution des jeux et des autres :tacles. In: BlÄNDDORF, J. (Ed.). Theather und Gesellschaft im Imperium manum. Mainz: Francke Verlag, 1990. p. 197-211.

CHA, E. Le génie de Tacite: la création des Annales. Bruxelles: H. Lamertin, 6 .

YET, J. Littérature Latine. Paris: Armand Colin, 1996.

LLEN, Heinz. Antike Staatsräson: Die Hinrichtung der 400 Sklaven des nischen Stadtpräfekten L. Pedanius Secundus im Jahre 61 n. Chr. Gymnasium, 39, 1982. p. 449-467.

RANGER, J. Imperium, expression et conception du pouvoir impérial. Revue i Études Latines, n. 55, 1977. p. 325-344.

INK, C. O. History in the Dialogus de Oratoribus and Tacitus the Historian: a $N$ approach to an old source. Hermes, n. 121, 1993. p. 335-349.

TTI DE LIMA, P. L'inchiesta e la prova: immagine storiografica, pratica giuridica storica nella Grecia classica. Torino: Einaudi, 1996.

IAPPETTA, A. Ad animos faciendos: comoção, fé e ficção nas Partitiones ttoriae e no De officiis de Cícero. São Paulo: FFLCH-USP, 1997. meografado.

ILE, A. Sine ira et studio. Rheinisches Museum für Philologie, n. 114, 1971. p. 43.

BBA, E. Modelli interpretativi nella storiografia antica. In: GABBA, E. Cultura ssica e storiografia moderna. Bologna: il Mulino, 1995. p. 331-344.

Rber, A. \& Greef, A. Lexicon Taciteum. Hildesheim: Georg Olms :lagbuchhandlung, 1962.

ODYEAR, F. R. D. Tacitus. In: Cambridge History of Classical Literature: The ly Principate, v. II, parte 4. Cambridge: Cambridge University Press, 1983. p. -159.

LMANN, W. 'Goldene Zeit' und geschichtliche Zeit im Dialogus de oratoribus: Geschichtsauffassung des Tacitus. Gymnasium, n. 96, 1989. p. 385-405.

Is, W. Libertas bei Tacitus. Hermes, n. 84, 1956. p. 331-352.

STNER, M. L. W. The greater Roman historians. Los Angeles: University of ifornia Press, 1977.

IE, T. J. Reading and response in the Dialogus. In: LucE, T. J.; Woodman, A. Eds.). Acitus and the tacitean tradition. New Jersey: Princeton University ss, 1993. p. 11-38. 
MARINCOLA, J. Authority and tradition in ancient historiography. Cambridge: Cambridge University Press, 1997.

MARSH, F. B. The reign of Tiberius. London: Oxford University Press, 1931.

Martin, R. Tacitus. London: Bristol Classical Press, 1989.

Murari Pires, Francisco. História e epopéia: os princípios da narrativa. In: Mithistória. São Paulo: Humanitas/FFLCH/USP, 1999. p. 147-276.

Shatzman, I. Tacitean rumours. Latomus - Revue D'Études Latines, n. 23, 1974. p. $549-478$.

SChellhase, Kenneth C. Tacitus in Renaissance Political Thought. Chicago: The University of Chicago Press, 1976.

SINCLAIR, P. Tacitus the sententious historian: a sociology of rhetoric in Annales 1-6. Pennsylvania: Pennsylvania State University Press, 1995.

SymE, R. Tacitus. Oxford: Oxford University Press, 1967.

TACrTE. Annales. Texte établi et traduit par Henri Goelzer. Paris: Les Belles Lettres, $1953.3 \mathrm{v}$.

TACrTE. Annales. Dialogue des Orateurs. Texte établi par Henri Goelzer et traduit par Henri Bornecque. Paris: Les Belles Lettres, 1936.

Von Albrecht, M. Storia della letteratura latina, v. II. Torino: Einaudi, 1995.

WEBER, Max. Economia y Sociedad: esbozo de sociología comprensiva. México: Fondo de Cultura Económica, 1996.

Woodman, A. J. Rhetoric in classical historiography. Portland: Areopagitica Press, 1988.

The literature of war. In: Woodman, A. J. Tacitus reviewed. Oxford: Clarendon Press, 1998a. p. 1-20.

. The preface of the Annals: more Sallust? In: . Tacitus reviewed.

Oxford: Clarendon Press, 1998b. p. 21-22.

. Tacitus on Tiberius' accession. In: Tacitus reviewed. Oxford:

Clarendon Press, 1998c. p. 40-69.

Lectorum incuria? In: Tacitus reviewed. Oxford: Clarendon Press, 1998d. p. 218-243.

Woodman, A. J; Kraus, C. S. Latin Historians. Greece \& Rome New Surveys in the Classics, n. 27. Oxford: Oxford University Press, 1997. 